
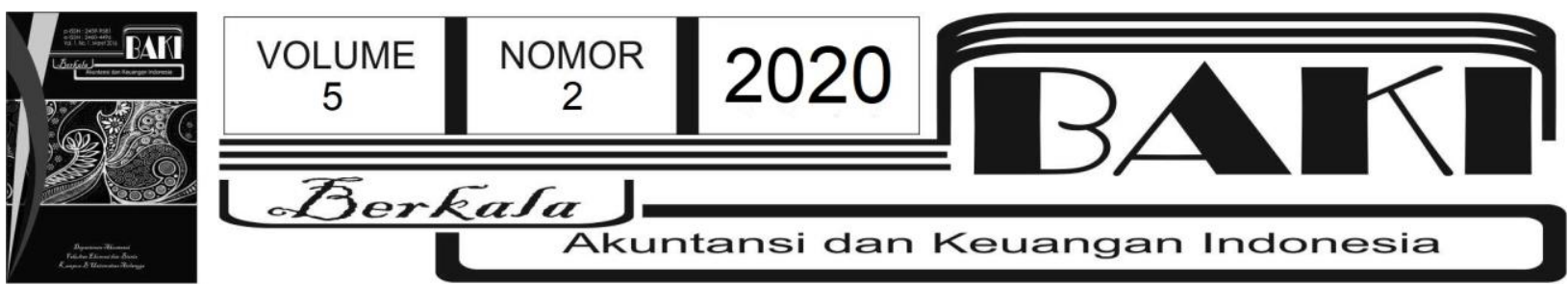

\title{
Analisis Kemampuan Informasi Laba dan Arus Kas dalam Memprediksi Arus Kas Masa Depan
}

\author{
Miranti Pangestu ${ }^{1}$ \\ 1 Universitas Sebelas Maret \\ 1pangestumiranti@gmail.com
}

\section{INFO ARTIKEL}

\section{Histori Artikel:}

Tanggal Masuk 14 Agustus 2020

Tanggal Diterima 27 Agustus 2020

Tersedia Online 30 September 2020

Keywords:
earnings, cash flow,
information, future cash
flow

\section{A BSTRACT}

The purpose of this study is to examine whether earnings information or cash flow information can predict future cash flows in service companies in Indonesia. The sample determined in this study, using the purposive sampling method, produced 145 companies listed on the Indonesian Stock Exchange in 2015-2017, with a total of 435 observations. In this study, multiple regression analysis techniques are used. The results shown by the t-test are partially significant net income. In this case, net income is a predictor of future cash flows. Whereas cash flow information namely operating cash flow, investing cash flow, and funding cash flow do not affect the future cash flow. Kata Kunci:
laba, arus kas, informasi,
arus kas masa depan

\section{ABSTRAK}

Tujuan dari penelitian ini ialah untuk menguji apakah informasi laba atau informasi arus kas memiliki kemampuan untuk memprediksi arus kas masa depan pada perusahaan jasa di Indonesia. Sampel yang ditetapkan pada penelitian ini, memakai metode purposive sampling menghasilkan 145 perusahaan yang tercatat di Bursa Efek Indonesia pada tahun 2015-2017, dengan jumlah amatan sebanyak 435. Dalam penelitian ini, teknik analisis regresi berganda merupakan teknik yang digunakan. Hasil yang ditunjukkan oleh uji t ialah laba bersih secara parsial berpengaruh signifikan. Dalam hal ini, laba bersih menjadi prediktor terhadap arus kas masa depan. Sedangkan informasi arus kas yakni arus kas operasi, arus kas investasi, serta arus kas pendanaan tidak berpengaruh terhadap arus kas masa depan. 


\section{Pendahuluan}

Banyak perusahaan-perusahaan dewasa ini, mengalami pemborosan arus kas, fenomena ini terjadi pada perusahaan jasa di Indonesia. Dilansir dalam Bareksa.com (Juni 2016) PT Bakrie \& Brothers Tbk mengalami kesulitan untuk membiayai operasional perusahaan sejak akhir tahun 2015. Arus kas operasi PT Bakrie \& Brother Tbk sepanjang Januari sampai Maret 2016 tercatat negatif Rp 107 miliar (Bareksa.com, Juni 2016). Pada tahun 2017, 4 perusahaan jasa yaitu PT Adhi Karya Tbk, PT Pembangunan Perumahan Tbk, PT Waskita Karya Tbk, dan PT Wijaya Karya Tbk mencatat penurunan arus kas operasi (Sindonews.com, Desember 2017). PT Indosat di tahun 2018 menghadapi kemerosotan arus kas operasi senilai Rp 4,16 triliun (Katadata.co.id, Maret 2019). Bank BJBR mencatat arus kas operasi defisit sebesar Rp 6,07 triliun di tahun 2018 (Bisnis.com, April 2019). Fenomena yang terjadi ini, dapat menyebabkan banyak perusahaan mengalami dampak negatif. Diantara dampak negatif yang akan terjadi adalah perusahaan tidak akan bertahan lama. Alih-alih berlomba untuk menaikkan laba, perusahaan diharapkan mampu untuk bertahan secara berkelanjutan.

Dunia usaha semakin berkembang, menuntut perusahaan untuk mencari cara agar dapat mempertahankan keberlangsungan kegiatan usaha perusahaan. Salah satu cara agar perusahaan dapat mempertahankan usahanya ialah memaksimalkan sumber daya yang terdapat dalam perusahaan. Dengan memanfaatkan serta memaksimalkan sumber daya yang telah tersedia, perusahaan akan mampu bekerja dan menjalani operasinya serta mencipta unjuk kerja perusahaan secara menyeluruh dan baik. Salah satu barometer guna mempresentasikan unjuk kerja perusahaan ialah pihak manajemen membuat laporan keuangan dengan konsisten dan ajek. Laporan keuangan oleh PSAK No. 1 (2015), ialah penyajian atas kinerja serta posisi keuangan suatu entitas. Yang menjadi tujuan laporan keuangan yaitu menginformasikan tentang arus kas, unjuk kerja keuangan, serta posisi keuangan suatu entitas, akan berguna bagi pemakai laporan keuangan untuk memutuskan sesuatu di bidang ekonomi (PSAK No. 1, 2015). Berkaitan dengan informasi dalam laporan keuangan, Financial Accounting Standard Boards di Statement of Financial Accounting Concept No. 1 menerangkan di dalam laporan keuangan itu, wajib terdapat informasiinformasi guna mendukung investor masa kini, kreditor, investor potensial, serta pemakai lain terkait menghitung jumlah, ketidakpastian, waktu, pelunasan yang berasal dari sekuritas atau utang, serta prospek atas penjualan oleh penerimaan pendapatan, dividen, dan bunga.

Laporan keuangan itu sendiri, meliputi laporan arus kas, laporan perubahan ekuitas, laporan laba rugi dan penghasilan komprehensif lain, laporan posisi keuangan, catatan atas laporan keuangan (PSAK No 1, 2015). Statement of Financial Accounting Concept no. 95 (1987) menerangkan jika laporan laba rugi dapat difungsikan menjadi fundamen dalam 
kaitannya memperkirakan arus kas masa depan. Komponen seperti profit, loss, income, dan expense dalam laporan laba rugi, mampu menghitung nilai risiko atas ketidakjelasan perolehan arus kas masa depan (Kieso et al., 2016). Kieso et al. (2016) menerangkan laba bersih dalam laporan laporan laba rugi ialah pengurangan antara income dari aktivitas operasi dengan income dari aktivitas bukan operasi perusahaan. Informasi yang terkandung di laba bersih bisa membantu para pemakai laporan keuangan guna memperhitungkan prospek entitas di masa depan.

Selain laporan laba rugi, PSAK No. 2 (2015) menyampaikan jika perusahaan wajib merumuskan laporan arus kas serta laporan arus kas disajikan menjadi segmen yang tak bisa dipecahkan dari laporan keuangan. Laporan arus kas menyajikan penjelasan kaitannya dengan laporan dari keuangan lain bisa bermanfaat guna kepentingan, seperti menilai kapabilitas perusahaan memberikan hasil berupa setara kas dan kas, mengembangkan model yang memudahkan bagi pemakai informasi dalam menimbang-nimbang nilai sekarang dengan arus kas masa depan perusahaan (PSAK No. 2, 2015). Arus kas dapat dipecah jadi tiga komponen, yakni arus kas dari aktivitas pendanaan, arus kas dari aktivitas investasi, serta arus kas dari aktivitas operasi. Ketiga komponen tersebut serta informasi lain dalam laporan keuangan bisa dikembangkan sebagai model yang berguna menjadi pembanding nilai saat ini dari future cash flow oleh para pengguna laporan keuangan (Yuwana dan Christiawan, 2014).

Sampai saat ini, penelitian terkait dengan arus kas masa depan sudah banyak dilakukan. Beberapa hasil penelitian yang mendukung, berkaitan dengan kemampuan laba yang lebih unggul dibanding arus kas dalam memprediksi arus kas masa depan adalah Al-Attar dan Maali (2017), Agana et al. (2015), Bagheri et al. (2012), Shubita (2013), serta Ebaid (2011). Selain laba, penelitian sebelumnya membuktikan jika kaitannya dengan arus kas masa depan, arus kas mempunyai kemampuan prediktif lebih unggul. Hal yang demikian didukung penelitian Mulenga (2015), Dawar (2015) dan Jemaa et al. (2015)

Penelitian ini mengacu pada penelitian Mulenga (2015) yang mengobservasi terkait kemampuan laba serta arus kas operasi dalam memperkirakan future cash flow dari operasi perusahaan India tahun 2002-2014 yang tercatat di Bursa Bombay. Penelitian Mulenga (2015) menggunakan laba sesudah pajak sebelum pos luar biasa serta arus kas operasi sebagai proksi, sedangkan penelitian ini lebih kepada komponen laba yaitu laba bersih dan komponen arus kas yakni arus kas operasi, arus kas investasi, serta arus kas pendanaan. Penelitian Mulenga (2015) meneliti atas perusahaan dalam Bursa Bombay di India, sedangkan pada penelitian ini meneliti lebih spesifik atas perusahaan jasa dalam Bursa Efek Indonesia dikarenakan peneliti mengacu pada fenomena yang terjadi pada perusahaan jasa terkait arus kas yang mengalami pemborosan. Tahun pengamatan yang dilakukan oleh Mulenga (2015) yaitu dari tahun 2002 hingga tahun 2014, sedangkan penelitian ini melakukan pengamatan 
yakni pada tahun 2015 hingga tahun 2017, dikarenakan fenomena yang terjadi di beberapa perusahaan jasa yang mengalami pemborosan arus kas sekitar akhir tahun 2015 hingga tahun 2018.

Berdasarkan latar belakang masalah yang sudah diuraikan dan dismilaritas dari hasil penelitian terdahulu, dapat diidentifikasi terkait apakah kandungan informasi laba dan kandungan informasi arus kas yakni arus kas operasi, arus kas investasi, serta arus kas pendanaan mempunyai kemampuan dalam memprediksi arus kas masa depan atau tidak. Tujuan pada penelitian ini guna memberikan jawaban rumusan masalah yang sudah dirinci sebelumnya, di antaranya, membuktikan secara empiris terkait kemampuan informasi laba bersih dalam memprediksi arus kas masa depan dan membuktikan secara empiris terkait kemampuan komponen arus kas yang meliputi arus kas operasi, arus kas investasi, serta arus kas pendanaan dalam memprediksi arus kas masa depan. Penelitian ini diharapkan bisa melengkapi penelitian yang lalu serta bermanfaat bagi berbagai pihak seperti bagi praktisi yang berguna sebagai objek evaluasi dalam pengambilan keputusan ekonomi, bagi akademisi yang berguna sebagai landasan dan pengembangan sarana pembelajaran terkait prediksi arus kas, serta bagi peneliti lain agar bisa menjadi rujukan pada isu yang sama.

Bagian selanjutnya dalam penelitian ini adalah landasan teori dan pengembangan hipotesis. Bagian yang ketiga menggambarkan metodologi penelitian sedangkan bagian yang keempat menjelaskan hasil penelitian. Lalu, Bagian yang terakhir berfokus kepada kesimpulan, saran, dan keterbatasan.

\section{Tinjauan Pustaka}

\subsection{Teori Sinyal}

Teori sinyal memberikan penafsiran, jika informasi yang disampaikan dari management pada outsiders sebagai sinyal untuk pasar. Teori sinyal oleh Besley dan Brigham (2008) merupakan aksi perusahaan tatkala memberi sinyal pada investor berkenaan pandangan manajemen terhadap prospek perusahaan. Dorongan perusahaan untuk memberikan sinyal tampak akibat muncul asymmetric information antara management dengan outsiders, yang mana investor mendapati informasi relatif lebih terbatas serta lebih lamban terkait internal perusahaan dibanding dengan management (Brigham dan Houston, 2005). Sinyal yang diberikan pihak manajemen pada pihak luar bisa disampaikan dengan informasi akuntansi yang diungkapkan yakni laporan keuangan (Brigham dan Houston, 2005). Laporan keuangan yang dipublikasikan akan digunakan oleh para pemakai laporan keuangan guna memperoleh dan mendapatkan informasi sebanyak-banyaknya yang tercantum dalam laporan keuangan. Informasi yang tercantum dalam laporan keuangan bisa berguna menjadi indikator dalam 
memperkirakan keuangan perusahaan di masa mendatang dan menilai unjuk kerja perusahaan.

Laporan keuangan meliputi laporan arus kas, laporan perubahan ekuitas, laporan laba rugi dan penghasilan komprehensif lain, laporan posisi keuangan, catatan atas laporan keuangan (PSAK No 1, 2015). Laporan laba rugi dapat difungsikan menjadi fundamen dalam kaitannya memperkirakan arus kas masa depan (SFAC No. 95, 1987). Informasi yang disediakan dalam laporan laba rugi dibutuhkan investor dan kreditor yang akan menunjang mereka memperkirakan jumlah, waktu, dan ketidakjelasan dari arus kas masa depan. Komponen seperti profit, loss, income, dan expense dalam laporan laba rugi, mampu menghitung nilai risiko atas ketidakjelasan perolehan future cash flow (Kieso et al., 2016). Laporan laba rugi, memuat laba bersih yang merupakan pengurangan antara income dari aktivitas operasi dengan income dari aktivitas bukan operasi perusahaan (Kieso et al., 2016).

Selain laporan laba rugi, PSAK No. 2 (2015) menerangkan jika perusahaan wajib merumuskan laporan arus kas serta laporan arus kas disajikan menjadi segmen yang tak bisa dipecahkan dari laporan keuangan. Laporan arus kas oleh PSAK No. 2 (2015), menyajikan penjelasan kaitannya dengan laporan dari keuangan lain bisa bermanfaat guna kepentingan, seperti menilai kapabilitas perusahaan memberikan hasil berupa setara kas dan kas, mengembangkan model yang memudahkan bagi pemakai informasi dalam menimbangnimbang nilai sekarang dengan arus kas masa depan perusahaan. Laporan arus kas dapat dipecah jadi tiga komponen yakni, arus kas dari aktivitas pendanaan, arus kas dari aktivitas investasi, serta arus kas dari aktivitas operasi. Ketiga komponen tersebut serta informasi lain dalam laporan keuangan bisa dikembangkan sebagai model yang berguna menjadi pembanding nilai saat ini dari future cash flow oleh para pengguna laporan keuangan (Yuwana dan Christiawan, 2014).

Sejalan dengan Godfrey et al. (2010) menerangkan jika teori sinyal menjelaskan tentang manajer yang menyampaikan sinyal dan target masa depan melalui akun-akun dalam laporan keuangan. Menurut Godfrey et al. (2010), manajer akan berusaha untuk memberikan sinyal melalui akun-akun dalam laporan keuangan, jika manajer menginginkan ambang pertumbuhan tinggi di masa depan. Peneliti melakukan analisis dengan memeriksa hubungan antar hubungan antar akun-akun dalam laporan laba rugi yaitu laba bersih dan pospos arus kas bersih berasal aktivitas operasi, aktivitas investasi, aktivitas pendanaan serta memeriksa apakah kemampuan informasi laba dan informasi arus kas perusahaan bisa memprediksi arus kas masa depan.

\subsection{Laporan Keuangan}

Laporan keuangan oleh Kieso et al. (2016) merupakan sebuah media komunikasi informasi keuangan fundamental pada pihak luar dari perusahaan. Yang disajikan dalam 
laporan keuangan ialah (1) laporan posisi keuangan, (2) laporan rugi laba, (3) laporan perubahan modal, dan (4) laporan arus kas serta catatan atas laporan keuangan adalah komponen terstruktur dari setiap laporan keuangan.

Tujuan laporan keuangan dibuat guna menginformasikan perihal kondisi perusahaan pada periode waktu tertentu kepada para pemakai laporan keuangan. PSAK No. 1 (2015) menerangkan tujuan dari laporan keuangan ialah menginformasikan berkenaan dengan arus kas, unjuk kerja keuangan, dan posisi keuangan entitas akan berguna bagi pemakai laporan keuangan untuk memutuskan sesuatu di bidang ekonomi.

\subsection{Laporan Laba Rugi}

Kieso et al. (2016) menerangkan jika laporan laba rugi ialah laporan yang menilai apakah operasi perusahaan mengalami keberhasilan sepanjang jangka waktu tertentu, menyajikan informasi dibutuhkan kreditor dan juga investor guna memperkirakan jumlah, ketidakjelasan arus kas masa depan, serta penetapan waktu. Laporan laba rugi ialah segmen dari laporan keuangan perusahaan yang menghasilkan laba maupun rugi bersih pada periode akuntansi yang disajikan oleh elemen biaya dan elemen pendapatan perusahaan.

Kieso et al. (2016) menjelaskan bahwasanya investor dan kreditor mengenakan informasi laba rugi untuk menilai unjuk kerja masa lalu perusahaan dan mengadakan fundamen untuk memperkirakan unjuk kerja di masa mendatang. Untuk menentukan tren penting yang mengandung informasi unjuk kerja masa depan maka perlu informasi dari unjuk kerja masa lalu. Komponen-komponen seperti income, expense, profit, dan loss dalam informasi laba mempresentasikan keterkaitan antara komponen tersebut dan mampu memperhitungkan nilai risiko pada tingkat khusus arus kas di masa akan datang.

\subsection{Laba}

Setiap perusahaan mengusahakan untuk mendapatkan laba yang optimal. Perusahaan yang memperoleh laba, laba tersebut akan berimbas terhadap keberlangsungan hidup perusahaan. Pengertian laba oleh Wild et al. (2005) menerangkan jika laba atau laba bersih menjelaskan profitabilitas perusahaan. Dalam Wild et al. (2005), laporan laba rugi memuat beberapa indikator profitabilitas antara lain: laba bersih yang mengindikasikan tentang profitabilitas perusahaan, laba kotor yang merupakan pengurangan antara sales dan cost of good sold, laba operasi yang merupakan pengurangan antara sales dan operation expense, laba sebelum pajak ialah laba operasi berlangsung sebelum cadangan income tax, dan laba operasi berjalan ialah laba dari usaha yang berlangsung sesudah bunga dan pajak.

\subsection{Laporan Arus Kas}


Arus kas ialah aliran arus kas keluar dan arus kas masuk atau setara kas (PSAK No. 2, 2015). Laporan arus kas ialah laporan keuangan yang mempresentasikan berkaitan dengan arus kas keluar dan masuk sepanjang jangka waktu tertentu. Yang merupakan tujuan laporan arus kas menurut Kieso et al. (2016) yakni menginformasikan terkait pembayaran tunai serta penerimaan kas sepanjang periode tertentu di perusahaan.

Dalam kegiatan usaha perusahaan aktivitas penting terkait laporan arus kas ialah kas yang diterima dan kas yang dibayar atas aktivitas operasi, aktivitas investasi, serta aktivitas pendanaan (Wild et al., 2005). Pengelompokkan arus kas dipecah jadi tiga, yakni: arus kas dari aktivitas operasi yang merupakan aktivitas penghasilan utama pendapatan meliputi aktivitas memproduksi barang atau jasa untuk diperjualkan, arus kas dari aktivitas investasi yang berasal dari aktivitas seperti penghentian dan pembelian berbagai aset serta pembelian dan penjualan surat-surat berharga, aktivitas investasi mencakup aset yang diinginkan mampu menghasilkan income perusahaan juga mencakup pokok pinjaman yang diberikan dan ditagih (Wild et al., 2005), arus kas dari aktivitas pendanaan mencakup pinjaman yang didapatkan oleh kreditor dan pokok pinjaman yang dibayarkan juga meliputi pengembalian investasi beserta penarikan dan kontribusi dari pihak pemilik (Wild et al., 2005).

\subsection{Penelitian Sebelumnya}

Hasil penelitian terdahulu dan mendukung, berkaitan dengan kemampuan laba dalam memprediksi arus kas masa depan ialah Al-Attar dan Maali (2017) yang meneliti pengaruh kualitas laba terhadap prediktabilitas akrual dan model arus kas dalam peramalan future cash flow pada perusahaan dalam Bursa Efek Jordania dengan hasilnya, kualitas laba memengaruhi prediksi pendapatan dan arus kas. Di dalamnya pendapatan mengungguli arus kas dalam memperkirakan future cash flow setahun selanjutnya kala menghasilkan kualitas tinggi. Agana et al. (2015) menarik kesimpulan dari penelitiannya tentang kemampuan prediktif perbandingan earnings dan operating cash flow di masa depan selama periode tahun 2002 sampai tahun 2012 pada perusahaan di Ghana bahwa laba ialah predictor yang lebih unggul daripada arus kas operasi historis dalam memperkirakan future cash flow. Shubita (2013) meneliti di Bursa Efek Amman dengan sampel sebanyak 66 perusahaan selama periode 2006-2011, hasilnya bahwa laba bersama beban depresiasi dan amortisasi mempunyai kemampuan predictive lebih unggul daripada arus kas operasi terlapor. Penelitian Ebaid (2011) menguji kemampuan prediksi earnings dan cash flow serta menguji kemungkinan disagregasi laba menjadi komponen akrual serta cash flow dalam meningkatkan kemampuan prediksi future cash flow yang melibatkan perusahaan Mesir selama tahun 1999 hingga tahun 2007, hasilnya laba agregat mampu memperkirakan arus kas mendatang lebih baik dari arus kas masa kini. 
Penelitian terdahulu yang mendukung kemampuan arus kas dalam memperkirakan arus kas masa depan adalah penelitian Mulenga (2015) pada 26 perusahaan India di Bursa Bombay tahun 2002 sampai 2014 dalam memprediksi future cash flow, dengan hasil bahwa model peramalan dengan operating cash flow sebagai predictor memiliki kekuatan lebih besar dari model earnings sebagai predictor dalam memperkirakan future cash flow. Penelitian Dawar (2015) meneliti dalam kasus perusahaan-perusahaan yang mematuhi Syariah di India dengan jangka waktu 10 tahun, hasilnya arus kas saat ini lebih unggul dari arus kas periode berikutnya daripada laba agregat saat ini dalam kemampuan prediksinya. Andayani dan Wirajaya (2015) meneliti perusahaan manufaktur berjumlah 40 periode 2011-2013 di $\mathrm{BEl}$, hasilnya variabel bebas yaitu arus kas operasi mempunyai kemampuan dalam memperkirakan future cash flow, sedangkan variabel bebas lain seperti modal kerja operasional, laba ditambah depresiasi, dan laba tidak mempunyai kemampuan prakiraan.

Penelitian lain terkait arus kas masa depan ialah penelitian Laksmi dan Ratnadi (2014) meneliti di perusahaan Consumer Goods periode 2005-2012 tercatat dalam Bursa Efek Indonesia, dengan kesimpulan arus kas operasi mempunyai kemampuan tidak berlainan dibanding laba bersih dalam memperkirakan future cash flow. Nasseri et al. (2018) menguji kausalitas antara cash flow dan earnings menggunakan 155 perusahaan di Bursa Efek Teheran untuk periode 2000-2009, dengan hasilnya adalah ada hubungan kausal dua arah antara cash flow dan earnings pada tingkat semua perusahaan individu.

\subsection{Perumusan Hipotesis}

Menurut Kieso et al. (2016), laba bersih mampu memberikan informasi menunjukkan pengurangan antara income aktivitas operasi dengan income aktivitas bukan operasi perusahaan. Informasi mengenai angka laba bersih pada laporan keuangan memberi kemudahan untuk memperkirakan arus kas masa depan secara tepat dan akurat dikarenakan informasi arus kas melalui akun laba bersih periode saat kini dapat merepresentasikan kelanjutan arus kas di masa depan (Yuwana dan Crishtiawan, 2014).

Laba bersih berkaitan dengan arus kas, informasi berkaitan arus kas perusahaan masa kini serta arus kas yang diinginkan dapat disampaikan melalui akun laba bersih periode saat kini (Yuwana dan Crishtiawan, 2014). Maka, bila laba bersih lebih besar daripada prakiraan laba, arus kas saat kini bakal lebih besar daripada prakiraan arus kas serta rerata prakiraan arus kas mendatang akan naik.

Temuan dari penelitian Ebaid (2011) yang menggunakan variabel independen salah satunya laba bersih, laba bersih mengindikasikan informasi yang relevan dalam memperkirakan future cash flow. Nasrollah (2013) menemukan bukti laba bersih secara signifikan mempunyai kemampuan dalam memperkirakan future cash flow. Jemaa et al. (2015), 
meneliti perihal menguji laba akuntansi mempunyai kemampuan terhadap arus kas untuk memperkirakan future cash flow dalam konteks Tunisia di 37 perusahaan tahun 1998-2012, dengan hasil bahwa laba bersih memiliki kapasitas prediksi paling menarik pada model penelitian yang menggabungkan penundaan satu dan dua tahun. Berdasarkan kajian teoretis dan empiris di atas, hipotesis pertama dalam penelitian ini ialah:

\section{$\mathrm{H}_{1}$ : Laba bersih mempunyai kemampuan memprediksi arus kas masa depan.}

Mengkaji keterkaitan hubungan antar komponen yang memengaruhi arus kas dan arus kas yang didapat dari aktivitas operasi mampu untuk memperkirakan arus kas di masa depan (Kieso et al., 2016). Penanda yang dapat memberi hasil apakah arus kas dari operasi perusahaan mampu dalam membayar dividen atau utang dan mengusahakan operasi perusahaan, berasal pada jumlah arus kas dari aktivitas operasi.

Arus kas operasi bisa diperkirakan sebelumnya dikarenakan arus kas operasi sebagian besar bersumber pada aktivitas repetitif yang dilakukan berkelanjutan (Nany, 2013). Jadi, arus kas operasi saat ini menjadi prediktor bagi arus kas mendatang, lantaran arus kas pada tahun berjalan bisa berulang kembali di tahun selanjutnya.

Mulenga (2015) menguji future cash flow dengan variabel bebas yakni arus kas dari aktivitas operasi. Hasilnya, model peramalan dengan variabel bebas yakni arus kas operasi sebagai predictor mempunyai kekuatan lebih besar dalam memperkirakan future cash flow dari peramalan model dengan variabel bebas lainnya yakni laba sebagai predictor. Penelitian Jemaa, et al. (2015) menerangkan bahwa arus kas operasi adalah prediktor yang menarik pada model sederhana berdasarkan delay satu tahun atau dua tahun. Berdasarkan kajian teoretis dan empiris di atas, hipotesis kedua pada penelitian ini ialah:

\section{$\mathrm{H}_{2}$ : Komponen arus kas operasi mempunyai kemampuan memprediksi arus kas masa depan.}

Dalam aktivitas investasi mencakup investasi lain bukan setara kas dan aset jangka panjang yang diperoleh atau dilepas, meliputi memperoleh investasi, menjual investasi, dan meminjamkan utang serta mengumpulkan piutang. Pendapatan serta arus kas masa depan bisa dihasilkan melalui sumber daya arus kas investasi yang diperoleh dari aktivitas pengeluaran kas. PSAK No. 2 (2015) menerangkan arus kas dari aktivitas investasi perlu untuk melakukan pengungkapan terpisah, lantaran arus kas investasi merepresentasikan pengeluaran dan penerimaan kas atas sumber daya yang bertujuan menghasilkan arus kas masa mendatang dan juga pendapatan.

Bertambahnya arus kas dari aktivitas investasi mengindikasikan perusahaan melangsungkan penjualan fixed asset atau investment asset perusahaan, dan sebaliknya berkurangnya arus kas dari aktivitas investasi mengindikasikan perusahaan melangsungkan 
ada pembelian dari aktivitas investasi maupun investasi di fixed asset guna menghasilkan income dan future cash flow.

Penelitian oleh Bandi dan Rahmawati (2005) menggunakan variabel bebas yakni arus kas investasi, hasilnya arus kas investasi mempunyai kemampuan dalam memperkirakan future cash flow. Berdasarkan kajian teoretis dan empiris di atas, hipotesis ketiga pada penelitian ini ialah:

\section{$\mathrm{H}_{3}$ : Komponen arus kas investasi mempunyai kemampuan memprediksi arus kas masa depan.}

Dalam aktivitas pendanaan mencakup pos-pos ekuitas pemegang saham dan kewajiban (PSAK No. 2, 2015). Arus kas pendanaan ialah arus kas yang bersumber pada kegiatan seperti pembayaran dividen, saham atau obligasi yang terbit, pembayaran utang dan peminjaman, serta buyback saham. PSAK No.2 (2015) menerangkan arus kas dari dari aktivitas pendanaan perlu untuk melakukan pengungkapan terpisah, lantaran pemasok untuk modal perusahaan dapat memperkirakan klaim terhadap arus kas di masa akan datang.

Arus kas pendanaan memberikan sinyal positif untuk investor. Arus kas dari aktivitas pendanaan dijadikan investor sebagai parameter dalam menetapkan keputusan investasi memprediksi claim dan future cash flow perusahaan.

Penelitian oleh Bandi dan Rahmawati (2005) menggunakan variabel bebas yakni arus kas pendanaan dengan hasil arus kas pendanaan mempunyai kemampuan dalam memprediksi future cash flow. Berdasarkan kajian teoretis dan empiris di atas, hipotesis keempat pada penelitian ini ialah:

\section{$\mathrm{H}_{4}$ : Komponen arus kas pendanaan mempunyai kemampuan memprediksi arus kas masa} depan.

\section{Metodologi Penelitian}

\subsection{Objek Penelitian}

Perusahaan jasa yang tercatat di Bursa Efek tahun 2015 sampai 2017 merupakan populasi dalam penelitian ini. Populasi pada penelitian ini sebanyak 253 perusahaan jasa.

Teknik pengambilan sampel pada penelitian ini dengan nonprobability sampling method. Metode nonprobability sampling yang dipakai ialah purposive sampling dengan judgement sampling, yakni pengambilan sampel yang mengacu pada kriteria khusus sesuai dengan target telaah (Sekaran dan Bougie, 2013). Sampel dipilih judgement sampling berdasarkan kemampuannya memberikan informasi yang dibutuhkan peneliti (Sekaran dan Bougie, 2013). Adapun rerangka pemilihan sampel dilandaskan pada patokan antara lain: perusahaan jasa yang tercatat di Bursa Efek Indonesia dan laporan keuangan yang diterbitkan lengkap selama 
kurun pengamatan 2015-2017, laporan keuangan di perusahaan berakhir pada periode 31 Desember, perusahaan menyajikan laporan keuangan dengan mata uang Rupiah yang pada umumnya merupakan mata uang fungsional perusahaan, serta perusahaan jasa tidak mengalami rugi bersih selama pengamatan. Dengan kata lain, laba bersih tidak bernilai negatif. Hal ini mengacu pada penelitian sebelumnya yang melaporkan laba positif yaitu penelitian Dahler dan Febrianto (2006). Berdasar data sekunder dari www.idx.co.id, ada 145 perusahaan jasa atau sebanyak 435 data yang memenuhi kriteria dan terpilih sebagai sampel.

\subsection{Variabel Penelitian dan Definisi Operasional}

\subsubsection{Arus Kas Masa Depan}

Arus kas ialah pengeluaran serta penerimaan kas perusahaan sepanjang satu periode. Dalam kegiatan usaha perusahaan aktivitas penting terkait laporan arus kas ialah kas yang diterima dan kas yang dibayar atas aktivitas pendanaan, aktivitas investasi, serta aktivitas operasi (Wild et al., 2005). Di penelitian ini, arus kas masa depan diukur memakai total arus kas bersih ketiga komponen yakni aktivitas operasi, investasi, serta pendanaan atas akhir tahun periode sesudah tahun amatan ${ }_{t+1}$ yakni tahun 2016, 2017, 2018. Arus kas masa depan selanjutnya pada notasi persamaan akan disingkat menjadi AKM.

\subsubsection{Laba Bersih}

Definisi operasional dari laba bersih ialah laba sesudah pajak sebelum pos luar biasa. Laba bersih di ukur dengan menggunakan laba sesudah pajak sebelum ke pos luar biasa mengacu pada penelitian Laksmi dan Ratnadi (2014), dan Ebaid et al. (2011). Periode pengamatan penelitian ini tahun 2015-2017. Laba Bersih depan selanjutnya pada notasi persamaan akan disingkat menjadi LB.

\subsubsection{Arus Kas dari Aktivitas Operasi}

Definisi arus kas dari aktivitas operasi ialah arus kas yang keluar dan masuk dari kegiatan operasi dilaporkan dalam laporan arus kas perusahaan (Jemaa et al., 2015). Pengukuran arus kas operasi memakai angka kas bersih yang diperoleh pada aktivitas operasi seperti penelitian dilakukan oleh Ebaid et al. (2011) dan Moeinanddin et al. (2012). Angka arus kas operasi memakai data dari laporan keuangan perusahaan jasa di BEI periode 2015-2017. Arus kas dari aktivitas operasi selanjutnya pada notasi persamaan akan disingkat menjadi AKO.

\subsubsection{Arus Kas dari Aktivitas Investasi}

Definisi arus kas dari aktivitas investasi ialah investasi lainnya bukan setara kas serta aset jangka panjang yang dilepas dan didapat (PSAK No. 2, 2015). Arus kas investasi diukur dengan angka kas bersih yang didapat pada aktivitas investasi memakai data dari laporan keuangan perusahaan jasa di BEI periode 2015-2017. Arus kas dari aktivitas investasi selanjutnya pada notasi persamaan akan disingkat menjadi AKI. 


\subsubsection{Arus Kas dari Aktivitas Pendanaan}

Definisi arus kas dari aktivitas pendanaan ialah aktivitas yang memicu pinjaman entitas, jumlah yang berubah, dan kompensasi modal (PSAK No. 2, 2015). Arus kas pendanaan diukur memakai angka kas bersih yang didapat pada aktivitas pendanaan memakai data dari laporan keuangan perusahaan jasa di BEI periode 2015-2017. Arus kas dari aktivitas pendanaan selanjutnya pada notasi persamaan akan disingkat menjadi AKP.

\subsection{Metode Analisis Data}

Uji asumsi klasik merupakan prasyarat untuk uji statistik deskriptif dalam analisis data pengujian ini, mencakup uji normalitas, uji multikolinieritas, uji autokolerasi, serta uji heteroskedastisitas. Uji normalitas memakai One Sample Kolmogrov-Smirnov Test untuk membuktikan normal atau tidaknya distribusi data dengan tingkat signifikansi sebesar $5 \%$. Data dalam penelitian dikatakan normal bila nilainya $>0,05$, dan tidak normal bila $<0,05$ (Ghozali, 2012). Uji multikolinearitas penelitian ini dilihat nilai VIF serta nilai tolerance. Bila nilai VIF $<10$ serta nilai tolerance $>0,01$ tidak terjadi multikolinieritas, begitu sebaliknya, bila nilai VIF $>10$ serta nilai tolerance $<0,01$ terjadi multikolinieritas. Run test dipakai untuk uji autokolerasi penelitian ini. Pada Run test, data dalam penelitian tidak terjadi autokorelasi, bila value asymp sig. > 0,05 (Ghozali, 2012). Pada uji heteroskedastisitas, penulis menggunakan uji glejser. Kriteria uji penelitian ini, bila asymp sig. di masing-masing variabel bebas atau independen adalah $>5 \%$, data tak terjadi heteroskedastisitas.

Metode analisis data selanjutnya adalah uji hipotesis dengan memakai analisis regresi berganda. Untuk persamaan regresi berganda pada pengujian hipotesis ialah:

$$
\begin{gathered}
Y=\alpha+\beta_{1} X_{1}+\beta_{2} X_{2}+\beta_{3} X_{3}+\beta_{4} X_{4}+e \\
A K M=\alpha+\beta_{1} L B+\beta_{2} A K O+\beta_{3} A K I+\beta_{4} A K P+e
\end{gathered}
$$

Keterangan:

$\mathrm{Y}=$ arus kas masa depan

$\alpha=$ konstanta

$\beta_{1}-\beta_{4}=$ koefisien regresi

$\mathrm{X}_{1}=$ laba bersih

$\mathrm{X}_{2}=$ arus kas operasi

$\mathrm{X}_{3}=$ arus kas investasi

$\mathrm{X}_{4}=$ arus kas pendanaan

$\mathrm{e}=$ error 
Penelitian hipotesis ini digunakan uji t guna melihat variabel bebas yakni laba bersih, arus kas operasi, arus kas investasi, serta arus kas pendanaan secara parsial berpengaruh signifikan pada predictor variabel terikat yakni arus kas masa depan. Uji goodness of fit memakai uji $\mathrm{F}$ yang bertujuan apakah variabel bebas yakni laba bersih, arus kas operasi, arus kas investasi, serta arus kas pendanaan secara simultan berpengaruh terhadap variabel terikat yakni arus kas masa depan secara signifikan. Koefisien determinasi oleh Ghozali (2012) bertujuan melihat presentase pengaruh variabel independen (bebas) atas variabel dependen (terikat). Besarnya variabel independen menjelaskan variabel dependen tergantung nilai adjusted $R^{2}$.

\section{Hasil dan Pembahasan}

\subsection{Hasil Pemilihan Sampel}

Berdasarkan kriteria pemilihan sampel pada bab sebelumnya dan metode purposive sampling dengan judgement sampling yang digunakan pada penelitian ini. Berikut tampilan tabel sampel pada penelitian ini:

Tabel 4.1

Prosedur Pemilihan Sampel

\begin{tabular}{lc} 
& Sampel \\
\hline Jumlah perusahaan jasa yang listing di BEI tahun 2015-2017 & 253 \\
Jumlah pengamatan selama tahun 2015-2017 & 759 \\
Perusahaan jasa yang tidak mempublikasikan laporan keuangan secara & $(39)$ \\
konsisten selama tahun 2015-2017 & \\
Laporan perusahaan yang tidak berakhir pada 31 Desember & $(0)$ \\
Perusahaan jasa yang mengalami rugi bersih & $(210)$ \\
Perusahaan jasa yang tidak mempublikasikan laporan keuangan & $(75)$ \\
menggunakan mata uang Rupiah & \\
Jumlah perusahaan sampel & 145 \\
Tahun pengamatan (tahun) & 3 \\
Jumlah sampel total selama periode penelitian & 435 \\
\hline
\end{tabular}

Sumber: data diolah (2020)

Sebanyak 435 amatan yang dijadikan sampel pada penelitian ini, didapatkan dari financial statement pada perusahaan jasa tahun 2015-2017 listing pada Bursa Efek Indonesia, laporan keuangan berakhir 31 Desember, data tersedia lengkap selama tahun 2015-2017, tidak mengalami rugi bersih, perusahaan memakai mata uang Rupiah untuk pelaporannya.

\subsection{Analisis Deskriptif}

Untuk mengetahui distribusi data sampel perlu dilakukan uji statistik. Berikut hasil pengolahan data meliputi nilai maksimum, nilai minimum, mean serta standar deviasi yang ditunjukkan dalam Tabel 4.2: 
Tabel 4.2

Hasil Statistik Deskriptif

\begin{tabular}{lrrrrr}
\hline & N & \multicolumn{1}{c}{ Minimum } & \multicolumn{1}{c}{ Maximum } & \multicolumn{1}{c}{ Mean } & \multicolumn{1}{c}{$\begin{array}{c}\text { Std. } \\
\text { Deviation }\end{array}$} \\
\hline AKM & 435 & 969534996 & 215757148000000 & 6108059218988.15 & 23309021872496900 \\
\hline LB & 435 & 128337162 & 32701000000000 & 1199120314561.69 & 4055824141127840 \\
\hline AKO & 435 & -7762413775203 & 49405000000000 & 1456204166433.92 & 6404261599235310 \\
\hline AKI & 435 & -58401942000000 & 3653802000000 & -1451844888469.76 & 5668732090356260 \\
\hline AKP & 435 & -21052000000000 & 22459333440495 & 273455794371.88 & 2681287156090250 \\
\hline
\end{tabular}

Sumber: Data sekunder diolah (2020)

Berdasar Tabel 2 hasil statistik, PT Hotel Mandarine Regency Tbk. di tahun 2016 mempunyai nilai arus kas masa depan ( $\mathrm{Y}$ ) terendah yakni Rp 969.534.996,00. Nilai maksimum untuk arus kas masa depan yakni Rp 215.757.148.000.000,00 dimiliki oleh PT Bank Rakyat Indonesia (Persero) Tbk di tahun 2017.

Nilai laba bersih (X1) terendah ialah PT Hotel Mandarine Regency Tbk. sebesar Rp 128.337.162,00 di tahun 2017. Nilai maksimum laba bersih yakni Rp 32.701.000.000.000,00 dimiliki PT Telekomunikasi Indonesia (Persero) Tbk. di tahun 2017.

Perusahaan sampel yang mempunyai nilai untuk arus kas operasi (X2) paling rendah ialah PT Waskita Karya (Persero) Tbk. sebesar Rp -7.762.413.775.203,00 pada tahun 2016. Nilai maksimum arus kas operasi dipunyai PT Telekomunikasi Indonesia (Persero) Tbk. di tahun 2017 yakni Rp 49.405.000.000.000,00.

Nilai arus kas investasi (X3) terendah ialah PT Bank Central Asia Tbk. di tahun 2016 yakni Rp -58.401.942.000.000,00. Nilai maksimum arus kas investasi yang jumlahnya Rp 3.653.802.000.000,00 dipunyai oleh PT Bank Pembangunan Daerah Jawa Barat dan Banten Tbk tahun 2016.

Perusahaan sampel yang mempunyai nilai untuk arus kas pendanaan (X4) terendah ialah PT Telekomunikasi Indonesia (Persero) Tbk. dengan jumlah Rp -21.052.000.000.000,00 tahun 2017. Nilai maksimum arus kas pendanaan dimiliki PT Waskita Karya (Persero) Tbk. sebesar Rp 22.459.333.440.495,00 pada tahun 2016.

\subsection{Analisis Regresi Berganda}

\subsubsection{Uji Normalitas}

Guna mengetahui apakah variabel terikat (dependen) dengan variabel bebas (independen) berdistribusi normal atau tidak normal dengan uji normalitas. Uji yang dipakai dalam penelitian ini yakni uji non parametrik Kolmogorov-Smirnov. Bisa dilihat hasil uji K-S dalam tabel: 
Tabel 4.3

Hasil Uji Normalitas

\begin{tabular}{ccccc}
\hline Variabel & $\mathbf{N}$ & $\begin{array}{c}\text { Kolmogorov- } \\
\text { Smirnov }\end{array}$ & $\begin{array}{c}\text { Asymp. Sig. (2- } \\
\text { tailed) }\end{array}$ & Kesimpulan \\
\hline $\begin{array}{c}\text { Unstandardized } \\
\text { Residual }\end{array}$ & 435 & 0,313 & 0,000 & $\begin{array}{c}\text { Distribusi Tidak } \\
\text { Normal }\end{array}$ \\
\hline
\end{tabular}

Sumber: Data sekunder diolah (2020)

Nilai Asymp.Sig (2-tailed) sebesar 0,00 mengindikasikan bahwa data tidak berdistribusi secara normal, dikarenakan nilai Asymp.Sig lebih kecil dari alpha 0,05. Karena data tidak normal perlu adanya perbaikan pada model regresi yang telah ditetapkan. Salah satu cara yakni dengan transformasi data, menjadikan variabel terikat maupun dengan variabel bebas dalam bentuk logaritma natural. Transformasi membuat persamaan model regresi menjadi:

$$
\operatorname{LnY}=\alpha+\beta_{1} \operatorname{Ln} X_{1}+\beta_{2} L n X_{2}+\beta_{3} L n X_{3}+\beta_{4} L n X_{4}+e
$$

Dari model regresi terbaru, berikut hasil uji Kolmogorov-Smirnov pada Tabel 4.3 dapat dicermati:

Tabel 4.4

Hasil Uji Normalitas

\begin{tabular}{ccccc}
\hline Variabel & $\mathbf{N}$ & $\begin{array}{c}\text { Kolmogorov- } \\
\text { Smirnov }\end{array}$ & $\begin{array}{c}\text { Asymp. Sig. (2- } \\
\text { tailed) }\end{array}$ & Kesimpulan \\
\hline $\begin{array}{c}\text { Unstandardized } \\
\text { Residual }\end{array}$ & 435 & 0,042 & 0,064 & Distribusi Normal \\
\hline Sumber: Data sekunder diolah (2020) & & & &
\end{tabular}

Diamati pada Tabel 4.3 untuk uji Komogorov-Smirnov nilai dari Asymp. Sig. (2-tailed) sebesar 0,064 lebih besar dari 0,05. Hal ini mengindikasikan model penelitian terkait data, berdistribusi secara normal.

\subsubsection{Uji Multikolinearitas}

Guna mengetahui dalam model regresi apakah variabel bebas saling berhubungan atau tidak, maka perlu uji multikolinearitas. Nilai VIF di bawah 10 serta tolerance value di atas 0,10 sebagai indikator untuk mengetahui data terjadi gejala multikolinearitas atau tidak (Ghozali, 2012). Bisa dilihat hasil uji multikolinearitas pada Tabel 4.5:

Tabel 4.5

Hasil Uji Multikolinearitas

\begin{tabular}{cccc}
\hline \multirow{2}{*}{ Variabel Independen } & \multicolumn{2}{c}{ Collinearity Statistics } & \multirow{2}{*}{ Kesimpulan } \\
\cline { 2 - 3 } & Tolerance & VIF & \multirow{2}{*}{ Tak terjadi Multikolinearitas } \\
\hline Ln_LB $(\mathbf{X} 1)$ & 0,910 & 1,099 & Tak terjadi Multikolinearitas \\
\hline Ln_AKO (X2) & 0,910 & 1,099 & Tak terjadi Multikolinearitas \\
\hline Ln_AKI (X3) & 0,915 & 1,092 & Tak terjadi Multikolinearitas \\
\hline Ln_AKP $(\mathbf{X})$ & 0,983 & 1,017 & T)
\end{tabular}

Sumber: Data sekunder diolah (2020) 
Dari Tabel 5 untuk uji multikolinearitas bisa dilihat nilai tolerance pada laba bersih (Ln_X1) sebesar 0,910 > 0,1 dan nilai VIF nya 1,099<10. Sebesar 0,0910 > 0,1 merupakan nilai tolerance pada arus kas operasi (Ln_X2) dan sebesar 1,099 $<10$ ialah nilai VIF arus kas operasi. Pada arus kas investasi (Ln_X3) nilai tolerance dengan nilai 0,915 $>0,1$ serta nilai VIF dengan nilai 1,092 < 10. Pada arus kas pendanaan ( $\left.L n \_X 4\right)$ nilai tolerance nilainya 0,983 > 0,1 serta nilai VIF nilainya $1,017<10$. Dari hasil yang telah dijabarkan bisa disimpulkan tak terjadi multikolinearitas di model regresi untuk penelitian ini.

\subsubsection{Uji Autokorelasi}

Agar bisa mengetahui kolerasi yang terjadi pada model regresi dilakukan uji autokolerasi. Runs Test dipakai untuk mengetahui gejala kolerasi pada model penelitian ini. Nilai signifikansi lebih besar dari 0,05 sebagai indikasi tak terjadi autokolerasi (Ghozali, 2012). Bisa dilihat penyajian hasil Run test pada Tabel 4.6:

Tabel 4.6

Hasil Uji Autokolerasi

\begin{tabular}{lr}
\hline & Unstandardized Residual \\
\hline Test Value $^{\text {a }}$ & $-0,07406$ \\
\hline Total Cases & 435 \\
\hline Asymp. Sig. (2-tailed) & 0,076 \\
\hline Sumber: Data sekunder diolah (2020)
\end{tabular}

Nilai Asymp. Sig. (2-tailed) dapat diamati di Tabel 6 dengan nilai 0,076 >0,05. Bisa disimpulkan model regresi untuk penelitian ini tak terjadi autokolerasi.

\subsubsection{Uji Heteroskedastisitas}

Guna mengetahui apakah model penelitian terjadi heteroskedastisitas atau tidak dengan uji heteroskedastisitas. Uji Glejser dipakai dalam penelitian ini guna mengetahui terjadi gejala heteroskedastisitas atau tidak. Berikut penyajian hasil uji heteroskedastisitas pada Tabel 4.7:

Tabel 7

Hasil Uji Heteroskedastisitas

\begin{tabular}{|c|c|c|c|c|c|c|}
\hline & $\begin{array}{r}\text { Unstan } \\
\text { Coeff }\end{array}$ & $\begin{array}{l}\text { lardized } \\
\text { cients }\end{array}$ & $\begin{array}{c}\text { Standardized } \\
\text { Coefficients }\end{array}$ & t & Sig. & Kesimpulan \\
\hline & B & Std. Error & Beta & & & \\
\hline $\begin{array}{c}\operatorname{Ln}(\mathbf{X} 1) \\
\end{array}$ & 2,844 & 1,762 & & 1,613 & 0,107 & \\
\hline $\begin{array}{c}\text { Ln_AKO } \\
(\mathrm{X} 2) \\
\end{array}$ & $-0,038$ & 0,023 & $-0,082$ & $-1,640$ & 0,102 & $\begin{array}{c}\text { Tak terjadi } \\
\text { Heteroskedastisitas } \\
\end{array}$ \\
\hline $\begin{array}{c}\operatorname{Ln}(\mathrm{AKI} \\
(\mathrm{X} 3) \\
\end{array}$ & $-0,029$ & 0,053 & $-0,027$ & $-0,543$ & 0,587 & $\begin{array}{c}\text { Tak terjadi } \\
\text { Heteroskedastisitas } \\
\end{array}$ \\
\hline $\begin{array}{c}\operatorname{Ln}(\mathrm{AK} P) \\
(\end{array}$ & $-0,074$ & 0,056 & $-0,066$ & $-1,327$ & 0,185 & $\begin{array}{c}\text { Tak terjadi } \\
\text { Heteroskedastisitas } \\
\end{array}$ \\
\hline$\underset{(\mathrm{X} 1)}{\operatorname{Ln} \text { LB }}$ & 0,025 & 0,054 & 0,023 & 0,470 & 0,639 & $\begin{array}{c}\text { Tak terjadi } \\
\text { Heteroskedastisitas }\end{array}$ \\
\hline
\end{tabular}

Nilai sig. pada Tabel 7 untuk laba bersih (Ln_X1) yaitu 0,102 >0,05. sebesar 0,587 > 0,05 untuk nilai sig. arus kas operasi (Ln_X2). Untuk arus kas investasi (Ln_X3) nilai sig. nya 
sebesar $0,185>0,05$. Nilai sig. $0,639>0,05$ pada arus kas pendanaan (Ln_X4). Bisa disimpulkan tidak terdapat gejala heteroskedastisitas model regresi di penelitian ini.

\subsection{Uji Goodness of Fit}

Besarnya Adjusted $R$ Square merepresentasi dari koefisien regresi. Berikut penyajian hasil uji goodness of fit pada Tabel 4.8:

Tabel 4.8

Hasil Uji Goodness of Fit

\begin{tabular}{|c|c|c|c|}
\hline $\mathbf{R}$ & R Square & Adjusted R Square & Std. Error of the Estimate \\
\hline $0,781^{a}$ & 0,610 & 0,607 & 151,452 \\
\hline
\end{tabular}

Sumber: Data sekunder diolah (2020)

Nilai adjusted $R$-Square 0,607 menunjukkan jika 60,7\% variabel dependen (terikat) yakni arus kas masa depan bisa dijelaskan oleh variabel independen (bebas) yakni laba bersih, arus kas operasi, arus kas investasi, serta arus kas pendanaan. Lalu, persentase $39,3 \%$ yakni sisa dari $60,7 \%$ dapat dijelaskan variabel lain yang tak terdapat pada model ini.

Tabel 4.9

Hasil Uji Simultan (F)

\begin{tabular}{lrrrrr}
\hline & Sum of Squares & df & Mean Square & F & \multicolumn{1}{c}{ Sig. } \\
\hline Regression & 1.543 .650 & 4 & 385.912 & 168,245 & $0,000^{\text {b }}$ \\
\hline Residual & 986.315 & 430 & 2.294 & & \\
\hline Total & 2.529 .965 & 434 & & & \\
\hline
\end{tabular}

Sumber: Data sekunder diolah (2020)

Nilai dari $\mathrm{F}$ hitung yakni $168,245>$ dari nilai $2,3926 \mathrm{~F}$ tabel dengan sig. $0,00<0,05$ maka kesimpulannya model regresi sangat baik pada penelitian ini. Laba bersih, arus kas operasi, arus investasi, serta arus kas pendanaan secara simultan mempunyai kemampuan dalam memengaruhi variabel terikat yaitu arus kas masa depan.

\subsection{Uji Signifikansi Parameter Individual (Uji Statistik t)}

Untuk uji pengaruh variabel bebas terhadap variabel terikat. Hasil analisis regresi dapat ditunjukkan dalam Tabel 4.10 ialah:

Tabel 4.10

Hasil Uji Statistik t

\begin{tabular}{|c|c|c|c|c|c|}
\hline \multirow{2}{*}{ Variabel } & \multicolumn{2}{|c|}{ Unstandardized Coefficients } & \multirow{2}{*}{$\begin{array}{c}\begin{array}{c}\text { Standardized } \\
\text { Coefficients }\end{array} \\
\text { Beta }\end{array}$} & \multirow{2}{*}{$\mathbf{t}$} & \multirow{2}{*}{ Sig. } \\
\hline & B & Std. Error & & & \\
\hline (Constant) & 2.784 & 2.830 & & .984 & .326 \\
\hline Ln_LB (X1) & .924 & .037 & .779 & 24.670 & .000 \\
\hline Ln_AKO (X2) & .001 & .085 & .000 & .012 & .991 \\
\hline Ln_AKI (X3) & .005 & .089 & .002 & .054 & .957 \\
\hline Ln_AKP (X4) & -.067 & .086 & -.024 & -.774 & .439 \\
\hline
\end{tabular}

Sumber: Data sekunder diolah (2020) 
Untuk variabel laba bersih dengan nilai 0,924 merupakan nilai koefisien regresinya dan t hitung yaitu 24,670 serta nilai sig. yakni 0,00. Maka hipotesis pertama diterima. Pengaruh laba bersih terhadap arus kas masa depan berhasil dibuktikan pada penelitian ini. Hasil penelitian terdahulu juga mendukung hasil penelitian ini yakni Mulenga (2015), Jemaa et al. (2015), serta Laksmi dan Ratnadi (2014) yang menggunakan proksi laba bersih, membuktikan laba bersih mempunyai kemampuan dalam memperkirakan future cash flow. Ebaid (2011) juga membuktikan bila laba bersih sesudah pajak merupakan prediktor yang baik dari arus kas saat ini dalam memperkirakan future cash flow. Penelitian Shubita (2013) membuktikan bahwa laba bersih setelah pajak mempunyai kemampuan prediktif lebih baik dibandingkan arus kas operasi terlapor. Begitu pula, hasil penelitian Agana (2015) menunjukkan earnings serta operating cash flow signifikan dalam memperkirakan future cash flow tetapi laba memberikan keunggulan kemampuan prediksi komparatif pada arus kas masa depan karenanya daripada arus kas historis, laba ialah prediktor yang lebih unggul dalam memprediksi future cash flow. Menurut Joni (2011) informasi laba terhadap aliran kas operasi masa depan mempunyai kemampuan kekuatan prediksi. Hal ini memberi bukti bahwa jumlah laba tahun berjalan yang tinggi, jumlah arus kas masa depan juga akan tinggi. Laba bersih yang dihasilkan perusahaan mempunyai kemampuan dalam memprediksi arus kas masa depan terhadap perusahaan jasa yang tercatat di Bursa Efek Indonesia.

Untuk variabel arus kas operasi dengan nilai 0,001 merupakan nilai koefisien regresinya dan t hitung yaitu 0,012 serta nilai sig. yakni 0,991. Maka untuk pengujian arus kas operasi, hipotesis kedua ditolak. Hasil dari penelitian terdahulu yang tidak mendukung hasil penelitian ini yaitu Jemaa et al. (2015) dan Mulenga (2015) yang membuktikan arus kas operasi ialah predictor yang baik dalam memprediksi future cash flow. Tetapi, penelitian ini mendukung hasil penelitian Nany (2013), arus kas operasi yang tidak mempunyai kemampuan dalam memperkirakan future cash flow. Nany (2013) meneliti terkait arus kas operasi mempunyai kemampuan prediksi pada sektor industri berjumlah sembilan oleh Jakarta Stock Exchange Industrial Classification di tahun 2009-2010. Pada tiga sektor yakni industri keuangan, aneka industri, serta industri dasar kimia arus kas operasi tidak mempunyai kemampuan prediksi setahun selanjutnya. Hal ini memberi bukti arus kas operasi tahun berjalan tidak mempunyai kemampuan dalam memprediksi arus kas masa depan.

Untuk variabel arus kas investasi dengan nilai 0,005 merupakan koefisien regresinya dan $\mathrm{t}$ hitung yaitu 0,054 serta nilai sig. yakni 0,957. Maka pengujian arus kas investasi, hipotesis ketiga ditolak. Hasil dari penelitian terdahulu yang tidak mendukung hasil penelitian ini yaitu Bandi dan Rahmawati (2005) dan Suaidah (2017) yang memberikan bukti arus kas investasi berpengaruh dalam memperkirakan future cash flow. Hasil penelitian ini memberi bukti 
arus kas investasi tahun berjalan tidak mempunyai kemampuan dalam memprediksi arus kas masa depan.

Untuk variabel arus kas pendanaan dengan nilai -0,067 merupakan koefisien regresinya dan t hitung yaitu-0,774 serta nilai sig. yakni 0,439. Maka pengujian arus kas pendanaan, hipotesis keempat ditolak. Hasil penelitian terdahulu yang tidak mendukung hasil penelitian ini yaitu Bandi dan Rahmawati (2005) yang membuktikan bahwa arus kas pendanaan berpengaruh dalam memprediksi future cash flow. Tetapi, hasil penelitian Suaidah (2017) mendukung hasil penelitian ini bahwa arus dari aktivitas pendanaan tidak mempunyai kemampuan memprediksi future cash flow. Hal ini menunjukkan arus kas pendanaan tahun berjalan tidak mempunyai kemampuan dalam memprediksi arus kas masa depan. Persamaan model regresi berdasar hasil yang tertera di atas adalah:

$$
L n Y=2,784+0,924 L n L B+0,001 L n A K O+0,005 L n A K I-0,067 L n A K P+e
$$

\section{Kesimpulan}

Penelitian ini dilakukan guna menguji kemampuan informasi laba serta kemampuan informasi arus kas dalam memprediksi arus kas masa depan pada perusahaan jasa di Bursa Efek Indonesia periode 2015-2017. Berdasarkan hasil uji signifikasi parameter individual dengan tingkat signifikansi 5\%, dapat diambil kesimpulan yaitu: laba bersih mempunyai pengaruh yang signifikan terhadap arus kas masa depan, arus kas operasi mempunyai pengaruh positif tidak signifikan terhadap arus kas masa depan, arus kas investasi mempunyai pengaruh positif tidak signifikan terhadap arus kas masa depan, arus kas pendanaan mempunyai pengaruh negatif tidak signifikan terhadap arus kas masa depan.

Penelitian selanjutnya diharapkan memperluas dari segi periode pengamatan dan lingkup pengamatan untuk hasil yang lebih valid. Penelitian selanjutnya mungkin dapat menggunakan model lain seperti rasio keuangan serta menambahkan variabel kontrol untuk menangkap faktor lain yang memengaruhi arus kas.

Peneliti menyadari bahwa hasil uji yang dilakukan oleh peneliti mengalami beberapa keterbatasan yakni penelitian ini memakai hanya 3 tahun periode amatan sehingga jumlah sampel tergolong sedikit dibanding dengan penelitian sebelumnya, sampel penelitian terpaku pada perusahaan jasa yang terdapat di Bursa Efek Indonesia yang menghasilkan laba positif, penelitian ini ditemukan adanya pelanggaran asumsi normalitas, yang mempresentasikan pendistribusian data yang tak normal. Hal ini, membuat data perlu dilakukan transformasi variabel, sehingga mungkin saran untuk penelitian selanjutnya sebaiknya sejak awal pengukuran variabel langsung gunakan format logaritma natural (In) agar bagian normalitas yang terindikasi tidak normal dapat langsung dihapus. 


\section{Daftar Pustaka}

Agana, Joseph Akadeagre, Kwame Mireku, dan Kingsley Opoku Appiah. 2015. Comparative Predictive Abilities of Earnings and Operating Cash Flows on Future Cash Flows: Empirical Evidence from Ghana. Accounting and Finance Research. 4 (3): 40-45.

Al-Attar, Ali Mohammad, dan Bassam Mohammad Maali. 2017. The Effect of Earnings Quality on The Predictbaility of Accruals and Cash Flow Models in Forecasting Future Cash Flow. The Journal of Developing Areas. 51 (2): 45-58.

Bagheri, Seyedeh Maryam Babanejad, Abbasali Pouraghajan, Milad Emmgholipour, Elham Mansourinia, dan Fatemeh Adrang. 2012. The Evaluation of Accounting Earnings Component Ability in Predicting Future Operating Cash Flows: Evidence from Tehran Stock Exchange. Journal of Basic and Applied Scientific Research. 2 (12): 12379-12388.

Bandi dan Rahmawati. 2005. Relevansi Kandungan Informasi Komponen Arus Kas dan Laba dalam Memprediksi Arus Kas Masa Depan. Jurnal Akuntansi \& Bisnis. 5 (1): 27-42.

Bareksa.com. 2016. Arus Kas Operasi Negatif Jadi Alasan BNBR Terbitkan Obligasi Konversi. www.bareksa.com. diakses pada hari Sabtu 2 Mei 2020 pukul 11.00 WIB.

Besley, Scott. dan Eugene F. Brigham, 2008. Essential of Managerial Finance. Fourteen Edition. New Jersey: Pearson-Prentice Hall.

Bisnis.com. 2019. Arus Kas Operasi Bank BJB Defisit. www.bisnis.com. diakses pada hari Kamis 30 Januari 2020 pukul 14.30 WIB.

Brigham, Eugene F. dan Joel F. Houston. 2005. Manajemen Keuangan. Edisi kedelapan. Jakarta: Erlangga.

Brigham, Eugene F. dan Joel F. Houston. 2010. Dasar-Dasar Manajemen Keuangan. Edisi kesebelas. Jakarta: Erlangga.

Dahler, Yolanda dan Rahmat Febrianto. 2006. Kemampuan Prediktif Earnings dan Arus Kas dalam Memprediksi Arus Kas Masa Depan. Simposium Nasional Akuntansi 9 Padang.

Dawar, Varun. 2015. The Relative Predictive Ability of Earnings and Cash Flows. Management Research Review. 38 (4): 367 - 380.

Ebaid, Ibrahim El-Sayed. 2011. Accruals and The Prediction of Future Cash Flows. Management Research Review. 34(7). 838-853.

Financial Accounting Standard Board (FASB). 2000. SFAC No. 1. Objective of Financial Reporting by Business Enterprises.

Financial Accounting Standard Board (FASB). 1987. SFAC No. 95.

Godfrey, Jayne, Allan Hodgson, Ann Tarca, Keryn Holmes, dan Jane Hamilton. 2010. Accounting Theory. John Wiley \& Sons: Australia.

Ghozali, Imam. 2012. Aplikasi Analisis Multivariat dengan Program SPSS. Semarang: Badan Penerbit Universitas Diponegoro.

Habib, Ahsan. 2010. Prediction of Operating Cash Flows: Further Evidence from Australia. Australia Accounting Review. 20 (53): 134-143.

Ikatan Akuntansi Indonesia. 2015. Pernyataan Standar Akuntansi Keuangan. Indonesia: Ikatan Akuntan Indonesia.

Jemâa, Olfa Ben, Mohamed Toukabri, dan Faouzi Jilani. 2015. The Examination of the Ability of Earnings and Cash Flow in Predicting Future Cash Flows: Application to the Tunisian Context. Journal of Accounting and Finance Research, 4(1): 1-16.

Joni. 2011. Daya Prediksi Laba dan Aliran Kas (Studi Empiris pada Perusahaan Manufaktur di Bursa Efek Indonesia Periode 2005-2009). Jurnal Reviu Akuntansi dan Keuangan, 1(1): 39-48.

Katadata.co.id. 2019. Kas Adhi Karya Minus Rp 2,5 Triliun Akibat Proyek LRT Jabodetabek. www.katadata.co.id. diakses pada hari Minggu, 30 Desember 2019 pukul 14.00 WIB.

Katadata.co.id. 2019. Pendapatan Turun, Indosat Rugi Rp 2,4 Triliun pada 2018. www.katadata.co.id. diakses pada hari Minggu, 30 Desember 2019 pukul 14.10 WIB.

Kieso, Donald E., Jerry J. Weygandt, dan Terry. D. Warfield. 2016. Intermediate Accounting. New Jersey: John Wiley \& Sons (Asia) Pte Ltd. 
Laksmi, Ayu Indira dan Ni Made Dwi Ratnadi. 2014. Kemampuan Arus Kas dan Laba dalam Memprediksi Arus Kas Masa Depan. E-Jurnal Akuntansi Universitas Udayana. 9(1): 8896.

Moeinaddin, Mahmood, Saeid Saeida Ardakani, dan Fatemeh Akhoondzadeh. 2012. Examination The Ability of Earning and Cash Flow in Predicting Future Cash Flows. Interdisciplinary Journal of Contemporary Research in Business. 4(6): 94-101.

Mulenga, Mwila Joseph. 2015. The Relative Ability of Earnings and Cash Flow from Operations in Predicting Future Cash Flows: Evidence from India. International Journal of Accounting and Financial Reporting, 5(2): 178-194.

Nany, Magdalena. 2013. Analisis Kemampuan Prediksi Arus Kas Operasi (Studi pada Bursa Efek Indonesia). Jurnal Dinamika Akuntansi. 5(1): 35-46.

Nasseri, Ahmad, Mohammad Sayyadi, Hassan Yazdifar, Rasol Eskandari, dan Mohammad Aibahloul. 2018. Causality between Cash Flow and Earnings Evidence from Tehran (Iran) Stock Exchange. Journal of Emerging Market Finance. 17(2) 1-19.

Nasrollah, Takhtaei. 2013. Relative Ability of Earnings Data and Cash Flow in Predicting Future Cash Flows. Journal of Accounting Research. 3(1): 2162-3082

Syafriadi, Hepi. 2000. Kemampuan Earnings dan Arus Kas dalam Memprediksi Earnings dan Arus Kas Masa Depan. Jurnal Bisnis dan Akuntansi, 2 (1), 76-88.

Sekaran, Uma, dan Roger Bougie. 2013. Research Methods for Business. United Kingdom: Jhon Wiley \& Sons Ltd.

SindoNews.com. 2017. Arus Kas BUMN Negatif. www.sindonews.com. diakses pada hari Selasa, 31 Desember 2019 pukul 19.20 WIB.

Soewardjono. 2006. Teori Akuntansi Perekayasaan Laporan Keuangan. Edisi Ketiga.Yogyakarta: BPFE Yogyakarta.

Shubita, Mohammad Fawzi. 2013. The Forecasting Ability of Earnings and Operating Cash Flow. Interdiscplinary Journal of Contemporary Research in Business. 5 (3): 442-457.

Stice, Earl K., James D. Stice, dan K.Fred Skousen. 2004. Intermediate Acounting. Edisi kelimabelas. Jakarta: Salemba Empat.

Suaidah, Yuniep Mudjati. 2017. Kemampuan Informasi Komponen Arus Kas dan Laba dalam Memprediksi Arus Kas Masa Depan. Jurnal Riset Ekonomi dan Bisnis. 12 (2): 161-170.

Wild, John J., K. R. Subramanyam, dan Robert F. Halsey. 2005. Analisis Laporan Keuangan. Edisi Kedelapan. Jakarta: Salemba Empat.

Yuwana, Vina dan Yulius Jogi Christiawan. 2014. Analisis Kemampuan Laba dan Arus Kas Operasi dalam Memprediksi Arus Kas Operasi Masa Depan. Bussiness Acounting Review. 2 (1): 45-60.

www.idx.co.id diakses pada 1 Januari 2020

www.kbbi.id diakses pada 4 Januari 2020 